\title{
Religio-political Discourse and Jam'iyyat Ulema-i-Pakistan (JUP): A Careful Study of Different Narratives (1970-2003)
}

\author{
Dr. Mazher Hussain ${ }^{1}$, Dr. Shahid Hassan Rizvi ${ }^{2}$, Mian Saeed Ahmad ${ }^{3}$, Dr. Aftab Hussain Gillani ${ }^{4}$, Azra Nasreen Gillani ${ }^{5}$, \\ Almas Fatima ${ }^{6}$ \\ ${ }^{1}$ Lecturer, Department of History, the Islamia University of Bahawalpur, Pakistan \\ ${ }^{2}$ Associate Professor, Department of History, the Islamia University of Bahawalpur \\ ${ }^{3} \mathrm{PhD}$ Scholar, Department of History, the Islamia University of Bahawalpur \\ 4Associate Professor, Department of Pakistan Studies, the Islamia University of Bahawalpur \\ ${ }^{5} \mathrm{PhD}$ Scholar, Department of History, the Islamia University of Bahawalpur \\ ${ }^{6}$ Assistant Professor, Government Sadiq Women University, Bahawalpur \\ Correspondence: Dr. Mazher Hussain, Department of |History, the Islamia University of Bahawalpur, Pakistan.
}

Tel: +92-62-9255463, +92-321-7593576, +92-300-7080375

Received: March 14, 2016

doi:10.11114/ijsss.v4i6.1457
Accepted: April 18, 2016

Available online: April 20, 2016

\begin{abstract}
Barelvi Ulema, being active participants of the Pakistan Movement (1940-1947), very soon reached to the point that their objectives associated with the struggle for Pakistan could only be achieved through a constitutional and political struggle; and as per the need of the parliamentary system prevailed in the country, they must converge and consolidate their energies on a political platform. Hence, on $28^{\text {th }}$ March 1948, in a 3-day meeting of Barelvi ulema at Madrasah-i-Islamiah Arabiah Anwar al ulum, Multan, the Markazi (Central) Jam'iyyatal-Ulema-i-Pakistan (MJUP) was formally established. A glance over the party objectives set at this meeting gives a clear picture of JUP's Rightism sui generis. It was aspired that Pakistan would be a true Islamic state established through the promulgation of the Islamic constitution in the country and all the social and moral evils would be emulated as the founding father of the country had aspired in the inaugural session of the Constituent Assembly of Pakistan (CAP). Moreover, it was also hoped to propagate Islamic teachings among the Muslims by initiating the spirit of religious cum political awakening and the spirit of Jihad among them and direct their attention from western culture and civilization towards Islamic culture and civilization. Hence, the establishment of an Islamic state in the country was the destiny of JUP. In order to remind the higher authorities and other stakeholders responsible for the formation of the constitution, JUP held meetings and processions throughout the country. It pressed demands for the enforcement of Islamic jurisprudence through Islamic constitution. This religio-political as well as constitutional strife can be found in a number of indigenous narratives and beyond. The article presents a careful and curious study of different available narratives in this connection.
\end{abstract}

Keywords: Religio-political Discourse, Madrassa, Dictatorship, Socialism, Communism,

\section{Introduction}

\subsection{Jam'iyyat Ulama-i-Pakistan-JUP in Retrospect}

Before discussing the religion-politics interplay in the context of Jam'iyyat Ulama-i-Pakistan-JUP's Rightism, it is necessary to share a brief overview of its functioning for the convenience for those readers who generally never come across the activism of small religio-political parties which not only strive hard for their survival but also fight for the change of system abiding by country's constitution. It will cover its formation and an early interplay with the parties present on the political spectrum in Pakistan. It is pertinent to note that Jam'iyyat Ulama-i-Pakistan, comprising ulema from Barelvi faction-sub-sect of Sunni Hanafi School of Thought, was the first religious party which came into existence after the establishment of Pakistan. Till June 1970, it worked mainly as a religious party and supported ruling elites on various political issues. In the wake of 1970 general elections, the leadership of JUP redesigned its role and 
launched it as a religio-political party in order to take part in country's politics to implement its party programme if it got a chance to assume or share power.

Prior to the party's formation in 1948, the Barelvi leadership had supported All-India Muslim League, and after Pakistan's creation, it continued supporting Muslim League and Muhammad Ali Jinnah for greater Islamization in the new state. Failing to achieve this, it created the JUP for the "enforcement of Shariah as a confirmation and recognition of the Prophet and his deeds". The party's manifesto calls for implementation of the Quran and Sunnah, with courts enforcing Shariah.

Since the 1980s, due to both internal differences and external interference, the JUP although has lost much of its relevance and is divided into several splinter groups yet it strived hard to survive and sustain within country politics through waging electoral and political alliances in due course of time. In 1970 General Elections, the JUP won more seats than the Jama'at-i-Islami (JI) and as many as the Jam'iyyat Ulama-i-Islam (JUI) in the National Assembly. It also won the largest number of seats in Sindh after the PPP. Maulana Shah Ahmad Noorani, one of the JUP's stalwarts and party chairman (1970-2003) is credited with playing a key role "in preparing and evolving a consensus on the 1973 constitution". He was, however, unable to build a robust party apparatus and to mobilize Barelvi constituencies effectively, although the majority of Pakistanis belong to this Sunni sub-sect. As a result, he failed to consistently translate public support into electoral success.

Zia's eleven-year rule rendered the JUP almost insignificant. The party staunchly opposed military rule, due in part to its pro-democracy stance, but also because of Zia's espousal of Wahhabi Islam. Nor did the JUP support the anti-Soviet jihad in Afghanistan. According to party members, Zia provoked its internal rifts in order to minimize its impact, including by inviting some members to join his Majlis-i-Shura and promising them lands in return for their support. JUP members even argue that the MQM's creation was primarily meant to corrode the JUP, rather than the JI vote bank in the urban centres of Sindh, like Karachi and Hyderabad. As a matter of fact, the MQM did indeed eclipse an already diminishing party.

The JUP split over a disagreement during a 1990 by-election in Lahore about the party's relationship with the PML-N. As a result, Noorani's faction joined the Pakistani Awami Itehad, while another JUP leader, Maulana Abdul Sattar Niazi, led a faction that chose to ally with Sharif and the military-created alliance, the Islami Jamhuri Ittehad (IJI). JUP's stalwart Maulana Shah Ahmad Noorani's death in 2003 was followed by an internal leadership tussle from which the party has yet to recover. Today, his faction of the JUP remains a skeleton organization, with no written position on matters of foreign, economic or domestic policy, limiting its political involvement to occasional statements on religious issues.

\section{Religion-Politics Interplay in the Context of Jam'iyyat Ulama-I-Pakistan-JUP's Rightism}

Existing need to wage a critical study on religious political parties increases in an atmosphere where these parties are facing an awesome rather fierce criticism both from national and international fronts. Critics worldwide argue that because of Pakistan's ostensible identity as an Islamic state, an attempt in the early years had been made to create a state that conformed to an abstract Islamic model which according to them had proven impossible to define because of competing visions of an Islamic state.(Cohen, 2004)However, this claim needs further interpretations and inquiry which, indeed, needs a comprehensive scholarly effort to cope with. Furthermore; they are of the view that the most important conflict in Pakistan is not a civilization clash between Muslims and non-Muslims but a clash between different concepts of Islam, particularly how the Pakistani state should implement its Islamic identity. By tracing their roots to the colonial period these critics and scholars say that "Most of Pakistan's early leaders were liberal Muslims from North India and Bengal who believed in liberal democracy and did not want to create a state that dictated individual religious practices.(Cohen, 2004, pp.265-290) Their influence soon waned however, and 'Islamist' movements emerged in Pakistan (some led by influential scholars who migrated from India). These groups and individual have begun to wield considerable power and have long aspired to control the Pakistani state. They have never done well at the polls but have always been a factor in the street and through their reaching and preaching.(Cohen, 2004, pp.265-290) This view can be challenged on many grounds but the most reasonable is that most of the religious political parties believe in bringing change through political and electoral processes not through demonstrating street power or through heinous revolutionary activities. Secondly, it was their strong belief in ballot paper that demonstrated marvelous results in 2002 General Elections and emerged as one of the strong stakeholders or even power brokers in the country's politics. Even some hardliners blame the religious elements of the country, although they are in traces that the diverse Islamic parties and movements, ranging from radical groups that seek to foment a global Islamic revolution to factions that would be content to introduce more Muslim or Islamic elements into Pakistan itself.(Cohen, 2004, pp.265-290)The former would wage a Jihad in India to 'liberate' its 140 million Muslims.(Cohen, 2004, pp.265-290) Adding to the bitterness of their arguments, they even blame that some of these groups have also been active in Afghanistan (Note 1) and some had 
close ties with the Taliban (Note 2) and Al-Qaeda (Note 3). They would use the state of Pakistan as Trotsky (1879-1940) wanted to use the Soviet Union, a base for global revolution. (Note 4)

In the past these religious parties have played a vital role not only to curb Bhutto's Socialism, but also the self-aggrandizement of the former USSR to enforce Communist ideals to the country. They, at different occasions, articulated a united front (Note 5) to cope with the imported ideas repugnant to Islamic ideals. They even held a battle against Secularism, Socialism, and such other -isms and tendencies. However, some moderate critics are of the view that active religio-political parties see themselves as advocates of modernity, desisting Pakistan to be 'a marriage of Islam and technology.(Cohen, 2004, p.223) According to them most Pakistani Muslims are devout but not particularly radical and ethnic, linguistic, and economic issues, not religious ones, have dominated Pakistani politics. The power of the religious parties, they are of the view, derived from the patronage of the state; from General Ziaul Haq (1924-1988)'s times (Note 6) onward, the leaders used the religious parties to balance the secular and more influential Pakistan Muslim League and Pakistan people's Party (est. 1967).("Daily Jang," 1967) However, this is not true in the case of JUP which remained anti-Zia, even against every dictatorship to date.

In response to the questions raised by both ardent and moderate critics an elaborate inquiry is needed to analyze the discussion on the idea of making and Islamic state contrary to different isms and tendencies and the active role of religious political parties which their leaders aspire to play to make Pakistan a modern progressive state as per injections of religious teachings. A great volume of literature produced in Pakistan endeavors to elucidate the concept of an Islamic state and its universal validity in time and space. But despite of an agreement on assumption that such a concept exists, the debate reflects quite varied interpretations and some fundamental theoretical differences. At the same time, some people argue in favor of purely secular basis of the polity. The controversy, however, stems largely from the peculiar genesis of Pakistan because it was created on the basis of a claim of the Muslim league that the Muslims of the British India were a separate nation. The Muslim nation, it was asserted, had different aspirations and interests from the Hindu majority. This communal definition of nationhood was augmented with arguments emphasizing what was described as the distinct 'Islamic way of life'. For a proper and fuller realization of this way of life, it was maintained, an independent state of the Muslims was imperative.(Sayeed, 1967, pp.48-59)

Since independence in 1947, great intellectual effort has been expended on a theoretical exposition of the Islamic way of life. Central to the discussion have been questions about the role and purpose of the Islamic state. Several theories have been formulated in the context of the secular democratic alternative which Pakistan inherited as a legacy from the British period (1857-1947).(Khan, 2001, pp.273-298) A number of democratic rights had been conceded by the colonial government under presume from the people for self-government. Legislative assemblies, elected on qualified franchise and possessing limited powers, were functioning in many provinces. Ideas of universal adult franchise, sovereignty of the people etc, figured prominently in the leaders of the freedom movement. These included leaders of both the Muslim League and the Congress, most of them came from the westernized upper and middle classes.(Khan, 2001, p.299)

An adoption of secular parliamentary democracy in a more substantial sense, therefore, was on possible course which Pakistan could follow regarding the revived interest in creating an Islamic state, various interpretations obtain. According to one point of view, with the decline of western imperialist influence and the failure of Western institutions to take root into the third world, the former colonies and neo-colonies were led inevitably to revitalize their own political traditions and to recast their political systems in the mould of their historical past. In the case of the Muslim world, since there was no separation in Islam between the spiritual and temporal realms, and therefore, polities could not be divorced from religion, the idea of an Islamic state, it is asserted, is the rekindling of the typical Islamic political ethos.(Symonds, 1987, p.89)

Another stand point asserts that the undemocratic nature of Islamic political ideology popularized in the present times by fundamental ideologues, commends it to regimes which have no popular support and need to find some sort of legitimacy. The relationship between Islam and politics, and the implications which flow from such a relationship in modern times for the Muslim society has been the subject of several scholarly contributions. Especially since the Iranian revolution (Note 7), the subjects of Islamic states, Islamic polities, and Islamic economy and so on, have been figured frequently in newspapers all over the world. Many books of journalistic merit, both serious and sensational, have appeared on these topics. In addition, a number of specialized periodicals exist which deal almost exclusively with Islamic political studies. However, while there is an abundance of popular writings, serious analytical works are rather few. Hence, there is a need to examine, on the one hand, selected writings which shed light on contemporary political and ideological trends in the Muslim world so that trends obtaining in Pakistan can be placed in the context of wider, historically evolved cultural and political background, and on the other hand, to examine major existing scholarly studies which focus on the idea of making Pakistan an Islamic state, as serious and sincere political parties in Pakistan like JUP spire to inculcate in the long run. 
The material on religion and politics in Pakistan is abundant but not directly related, interconnected and lacking necessary details about the JUP, the ignored religious-cum-political party by both the political scientist as well as the historians on account of a number of reasons which will be discussed time and again where ever necessary in the forthcoming discussion. Even the role of JUP as a rightist party is missing in the chronicles of the country's history. Hence the gap is liable to be filled through the effort at hand. The years between 1970 and 2003 were the prime time of JUP and details on its role as a rightist party during this period can be found in fragmentation in different narratives.

The early works on religion and politics in Pakistan give short, plain and naive details and miss very details on minor political parties. One of these early works is Cesar P. Pobre's "History of Political Parties in Pakistan (1947-1958).(Cesar P. Probre, 1970, pp.314-315)It enlists political parties present in the country on the eve of the partition of the south-Asian subcontinent and throws some light on the functioning of these parties. Its chapters 'Political Parties in Action-I' and 'Political Parties in Action-II' cover the party activism, especially in provincial politics. It also gives details on the nature of party organization in the country and role of the leadership, party members in it. The writer concludes the work with the answer to the question of "workability of parliamentary government in Pakistan'. It was the malfunctioning and heinous designs of the party leaders which gave way to the first martial law in the country. The very interesting aspect covered by the writer in this work is the place of Islam in the nascent state of Pakistan. According to him Pakistan was conceived, carried and nourished in the womb of Islam. It was created because of Islam. It survived because of Islam and it had and continued to have meaning because of Islam. In other words, Pakistan's raison d'être was Islam and the question, therefore, to be decided when it came into being was how to make it Islamic. He asserts that the answer to this question, fundamental and all pervading as it was, proved to be as elusive as Pakistani leaders were neither decisive nor clear as to the extent to which Islam should be reflected in the new state. He concludes the discussion in the following words:

"On the end of the question were those who wanted to drawing a demarcation line between religion and politics-those who were prepared to 'render unto Caesar what is due to Caesar and unto God what is due to God.' They were for a purely secular Pakistan, allowing Islam to spread through and get into every part of the people's individual lives but not their collective and social life. On the other, were those who believed state and politics were not the two faces of the same coin but integral and in no way separable parts of the whole - which is Islam.' Associated with these Pakistanis were the ulema, the 'traditional leaders of traditional Islam.' They stood for a truly Islamic state, a Pakistan that was to be managed and molded strictly in accordance with the principles, laws, traditions, injunctions and prescriptions of Islam. In short, whereas at the one end were those who wanted separation of Religion and State, those at the other desired no such distinction. Between these two extremes were the moderates-want of a better term-who liked to synthesize the worldly and the other-worldly. They wanted to direct Pakistan along Islamic and at the same time modern lines. "(Cesar P. Probre, 1970, p.315)

Following the same model presented by Cesar P. Probre, a number of works on religion and politics in Pakistan were compiled, covering different time periods and regimes - both democratic and dictatorial one. Some of these works include Rafique Afzal's "Political Parties of Pakistan" in four extended volumes, covering the time period from 1947 to 1988, K. K. Aziz's Party Politics in Pakistan (1947-1958). The works of both Rafique Afzal and K. K. Aziz on the period 1947-1958 can be considered the replica of Cesar P. Probre's work discussed above, in historical and topical framework. While the second volume of Rafique Afzal works, "Political Parties in Pakistan 1958-1969" attempts to study the development of political parties during the first martial law regime. The first chapter discusses the state of party politics under General Ayub's Martial Law and the regime's policies to contain and tame the politicians. The next two chapters analyze the 1962 Constitution and the subsequent amendments made to it and the regulative and restrictive measures to control the political parties. The religio-political parties and their activism have been discussed in the fifth chapter including Jamiat al-ulema-i-Pakistan (JUP), Nizam-i-Islam Party (NIP), Jamiat al-ulema-i-Islam (JUI), and Jama'at-i-Islami Pakistan (JIP). JUP occupies only one and a half page discussion in this work. JUP, according to Rafique Afzal, supported the first martial law regime in order to save auqaf (religious endowments) and in turn mobilized support for the regime at crucial moments. The JUP was the only religio-political party that did not join any movement organized by the opposition parties. The politics of alliances is the focus of seventh chapter in which alliances like National Democratic Front (NDF), Combined Opposition Parties (COP), and Pakistan Democratic Movement (PDM) have been discussed in detail. The formation of alliances was a newly introduced feature in party politics in 1960s in order to face the martial law designs collectively. The JUP used the tool of 'political alliances' adroitly and extensively throughout its history after 1970 in order to empower the religious right. In continuum, Mushtaq Ahmad's "Government and Politics in Pakistan", gives valuable details on formation and functioning of the political parties during 1947 and 1958, Muneer Ahmad's Politics in Pakistan 1947-1958, Ivor Jennings' "Constitutional Problems in Pakistan", W.C. Smith's "Pakistan as an Islamic State",Khalid Bin Sayeed's " Pakistan: The Formative Phase”, William Andrews and Uri, Ra'anan's, “The Politics of the Coup de' Etat: Five Case Studies”, Leonard Binder's 
"Religion and Politics in Pakistan", Lawrence Ziring's "The Ayub Khan Era", G.W. Choudhury’s "Constitutional Development in Pakistan", and "Democracy in Pakistan", Zarina Salamat's " Pakistan 1947-1958: A Historical Perspective”, Erwin Birnbaum's "Some Theoretical and Practical Aspects of the Islamic State of Pakistan", Rosenthal's "Islam in the Modern National State", Freeland Abbott's "Islam and Pakistan", Muhammad Asghar Khan's "Generals in Politics: 1958-1982", "Islam, Politics, and the State", "The Pakistan Experience: State and Religion”, "We have Learnt Nothing from History-- Pakistan: Politics and Military Power", Ishtiaq Hussain Qureshi's "Pakistan: An Islamic Democracy", Syed Abdul Quddus' “Towards an Islamic Destiny”, and Zakaria Rafiq's “The Struggle Within Islam: The Conflict Between Religion and Politics" explore a number of untraveled vistas about multifold early political history of Pakistan.

In the political history of Pakistan, the period between 1970 and 1988, termed as the second democratic era, is full of political fervor. Especially, dialectics between leftist Bhutto and the religio-political rightist parties is on the crest. Many works compiled during the period and afterwards provide fragmented details of this tussle, finally paving way for the advent of third martial law in the country. Some of the representative works on the period include Hassan AskariRizvi's "State and Society in Pakistan", Rounaq Jahan's "Pakistan: Failure in National Integration", Muhammad Asghar Khan's "Pakistan at the Cross Roads", Muhammad Waseem's "Pakistan under Martial Law 1977-85", "Politics and state in Pakistan", Lawrence Ziring's "Pakistan: the Enigma of the Political Development", "Pakistan in the Twentieth Century: A Political History", "Pakistan at the Crosscurrent of history", Emajuddin Ahmad's "Military Rule and the Myth of Democracy”, Manzuruddin Ahmad's “ Contemporary Pakistan: Politics, Economy and Society”, Mushtaq Ahmad's "Government and Politics in Pakistan", Tariq Ali's "Can Pakistan Survive? The Death of a State", Shahid JavedBurki's "Pakistan under Bhutto", "Pakistan under the Military: Eleven Years of Zia-ul-Haq", "State and Society in Pakistan 1971-77", "Pakistan: the Continuing Search for Nationhood", Rafi Raza's "Pakistan in Perspective 1947-1997", Ian Talbot's "Pakistan: A Modern History", and Syed Mujawar Hussain Shah's "Religion and Politics in Pakistan (1972-88)".

The religion and politics in Pakistan has received substantial consideration from the Western scholars but with variant views. A significant segment of these scholars treats Islam as a personal affair of the Muslims of Pakistan while, on contrary, another faction of scholars overemphasizes the outward manifestation of Islam on part of the Pakistani ulema. W. C. Smith and Keith Callard, for example, consider Islam a vibrant quest for magnificent values and its believers manifest their wishes in order to comply with it. Smith, in is ever inspiring thesis on Islam and politics i.e. Pakistan as an Islamic State, has put forward a number of queries on the nature of the state whether it is Islamic one or vice versa, meaning of Islam associated to it and how it can be transformed into a modern welfare Islamic State. As a matter of fact und Islam in India has undoubtedly given way to a state which is Pakistan itself. The birth of Pakistan, in its own, was above all expressions put forward in the days of freedom struggle by different factions. He is of the view that Islam has found a state, in the form of Pakistan, to manifest itself as a religion. Pakistanis desire their country to be based and make advancement in every walk of life on the ideals of Islam as they were promised during the concluding episode of Pakistan Movement and the society should be built on the notions of democracy, brotherhood and justice. However, he maintains that ulema in Pakistan, like reactionaries in all societies, use religion as a tool to fulfill their vested interests. At this point it is interesting to quote Syed Mujawar Hussain Shah's comments about Smith's standpoint about the Islamic phraseology when it is transported to the one derived from western traditions causes confusion in the minds of both readers and constitution experts. Shah comments that "the Objective Resolution speaks of God as 'absolute ruler' but when it is translated as 'sovereignty' it becomes 'startling' and is received 'with astonishments and apprehensions' by non-Muslims.”(Syed Mujawar Hussain Shah, n.d., p.57) Moreover, Smith treats the question of minorities in democratic contexts that even in Western democracies the minorities face the danger of being outlawed at the hands of numerical majorities. Here, Professor Keith Callard is slightly different from Smith's viewpoint while dealing with religion and politics in Pakistan. He highlights both the importance of Islam as a moral and integrating force and the role of ulema in interpreting Islam. He considers that Muslim intellectuals combined the Western notion of self-determination with that of religion in order to get a separate homeland for them as a religious nation-state. About the constitution making process, Keith Callard assumes that the desirable role of religion in a modern state was not handled proficiently while forming the 1956 Constitution. However, he is well aware of the fact that the Constitution has something to satisfy both sides - giving grounds to orthodox traditionalist that his cause may be advanced and accommodating liberal thinking too on the grounds that there was nothing in the Islamic clauses repugnant to it. His findings suggest that in spite of a great deal of discussion of the significance of the requirements of Islam for the new state, comparatively little attention has been paid to the less spectacular task of bringing the new laws and policiesinto conformity with those requirements. In comparison with the Islamic mode of democracy, Callard is of the view that western democracy is secular in nature though it is greatly influenced by Christianity while in Islam is the only basis for social morality in Pakistan.(Syed Mujawar Hussain Shah, n.d., p.57) 
Another valuable source worth mentioning on the theme under discussion is Leonard Binder's "Religion and Politics in Pakistan"(Binder, 1961). Binder considers Islam an 'outward expression' instead of mere 'philosophy'.(Syed Mujawar Hussain Shah, n.d., p.74) He presented his study into three distinct segments named 'Orientation', 'Substantiation' and 'Alteration' respectively. In 'Orientation', Binder argues on four variant attitudes towards Islam and the state. These attitudes comprise: views of ulema's traditionalist faction, conjecture of modernists on ijma, 'fundamentalist' attitude of Jama'at-i-Islami - a rightist cadre based religio-political party of the country, and the secularist viewpoint assumed by a small Westernized faction of the society. Binder terms aforesaid four factions as "four loosely organized social groupings" with different goals to meet. He deems that the ulema wanted to see Pakistan in traditionalist-classical terms, whereas the modernists believed in consensus amongst the heterogeneous sections of the community, the secularists aspired Pakistan to be a democratic state based on the notions of Western Democracy, and the Jama'at-i-Islami with its "purified fundamentalist" vision of Islam.(Syed Mujawar Hussain Shah, n.d., pp.77-78)

Binder's theory of 'Substantiation' is concerned mainly with the historic expediency of Muslim League to work for the attainment of an Islamic state, the endorsement of the OR and execution of the Board of Talimat-i-Islamia. The ulema, as a matter of fact, worked for the institutionalization of their functionality in the affairs of the state, and pledge for the Head of the state to be a Muslim. However, Binder gives a confused picture of the constitution making process by mixing it with an ordinary law-making process and ignores the execution of constitution as a tool to develop, substantiate, balance and harmonize democratic as well as administrative institution. Moreover, some questions remain unanswered even after perusing through the whole book that "why is there only interplay of four attitudes of variant groups and the overwhelming population remained passive or ignorant and did not participate in the overall functioning of the state?"(Syed Mujawar Hussain Shah, n.d., p.81) Even his formulation of "four loosely organized social groupings" is questionable on account of the lack of reasoning behind his argument. Interestingly, other groups were supposed to be in confrontation with 'fundamentalist' Jama'at-i-Islami, taking the largest space in the book, without any justification. The 'Alteration' in Binder's view was the changes occurred as a result of the religion-politics interaction. Hence the he devoted the third and last part of his study to it.(Syed Mujawar Hussain Shah, n.d., pp.86-87).

Narrowing the literature review on religion and politics in Pakistan and directing it towards the focal theme of study, it is high time to delineate Syed Mujawar Hussain Shah's solicited work on religion and politics.(Syed Mujawar Hussain Shah, n.d.) According to him the literature on religion and politics in Pakistan revolves around two themes: the conflicting role of religion in the making of Pakistan when it was used by the traditionalist ulema to negate the idea of territorial nationalism in South Asia and secondly by the modern advocates of the Pakistan Movement in a purely political context. In this study, he has attempted to analyze this correlation at five different levels comprising the state, political leadership, the political parties, elections and the parliament. He worked on the very dialectical theme of modernist-traditionalist antagonism leading to the manipulation of Islam to advance their particular political intents. Shah argues that "the modernists equated Islam with modern secular institutions while giving in few cosmetic changes in order to satisfy the ulema. They had not prepared themselves for the application of Islam in socio-economic systems of the country. At times they used Islam to mobilize public opinion or to satisfy their political aspiration bowing to agitation politics at home as well as the diplomatic obligations abroad. This view is clearly demonstrated during the period of Bhutto's rule. Moreover, this process, did not amount to any radical change in Pakistan's politics, but yielded more ground to political ambitions of ulema."(Syed Mujawar Hussain Shah, n.d.)

Shah, moreover, is of the view that Zia capably used Islam to curb Socialist Bhutto and prolong martial law through extra constitutional measures like delaying the elections up to his desired time span. He further used the tool of Islam in order to get legitimacy for his unlawful rule by ensuring the loyalty of the religious right of the country. While in preliminary chapter Shah categorically discusses the designs of different stakeholders who in one way or the other manipulated the very notion of Islam to achieve their pet objectives. These stakeholders, involved in the dialectics were the neo-traditionalists, the traditionalists, the moderates, the secularists or pragmatists and the pirs. Shah finds the roots of this milieu in the pre-partition independence movement when some of these stakeholders became active to secure their place in the nascent state of Pakistan. In continuation with this legacy; Shah covers different details of this right-centrist-left tussle up till the down fall of President General Muhammad Ayub Khan (1907-1974).(Note 8) Shah terms the enforcement of the OR, the first victory of neo-traditionalist-traditionalist entente over the modernists and secularists, viewing that the passage of this resolution was indubitably the first step towards the establishment of an Islamic state. However, the debate over the wording of the resolution reveals that although there was a great ambiguity in usage of the word "Islam" yet it served as a compromise among the three major contenders of power, the ulema, the feudal elite and the bureaucracy. The other issues besides this debate, as Shah Points out that, were the slow advancement on constitution making process, anti-Ahmadiyya movement which overwhelmed the political scene for next two decades or so and the entrance of military into politics which was a serious repercussion for the future of the democracy in the country.(Syed Mujawar Hussain Shah, n.d.) 
The religion-politics milieu entered into a new phase right in the start of 1970s with the announcement of the first general elections in the country. In the chapter, 'First General Elections' Shah not only explicates the nature and designs of the contesting right-left parties but also explains how these parties introduced requisite symbols and slogans to fascinate the electorate. Economic policies-- as they were apparent form the manifestoes of political parties, issue of regional autonomy demanded by Awami League for East Pakistan, Bhutto's Islamic Socialism and the ulema's views on socialism constituted the core theme of this episode. Bhutto's constitutional, legislative and Islamization measures constitute the argument of the third and the prime chapter. The dismemberment of East Pakistan and later its recognition as Bangladesh by the Bhutto government entailed towards serious repercussions both in the minds of rightist parties as well as the establishment of the country. Undoubtedly, the creation of Bangladesh led to an "identity crisis" for a nation which got recognition on the basis of "two-nation theory", a trauma that pervaded the attentive public psyche. A considerable conscientious portion of the society was of the view that "the secularized and Westernized Pakistani leaders had not only failed in creating a genuine 'Islamic state' based on the Islamic ideology of Pakistan, but had exhibited inordinate personal ambition and avarice." Moreover, they avowed that "their country would not have been dismembered if the governing elite had made a more sincere and dedicated commitment to the Islamic notions of equality, justice, brotherhood, consultation and consensus at one time that contributed to the conversion of Hindus to Islam in the Indian subcontinent, as well as to the creation of Pakistan itself.(Syed Mujawar Hussain Shah, n.d., p.23) About the "identity crisis", Shah is of the view that "the tragedy of the breakup of the country in the outlook of the political elite as well as the masses and they began to think more on Islamic terms. The remaining Pakistan consisted of four province having different traditions and attitudes. The country's identity crisis essentially involved reassessing Pakistan's raison d'être."(Syed Mujawar Hussain Shah, n.d.) Other hot debates of this chapter are ulema-Bhutto relationship, formation of the 1973 Constitution and the reemergence of the "Ahmadis Question". Although the religio-political right of the country did have the mandate like Bhutto yet they had succeeded in securing a number of Islamic provisions in the Constitution. This prop up gave way to an encouraged rightist strategy which culminated in its energetic, triumphant agitation movement in the name Nizam-i-Mustafa (enforcement of Islamic socio-economic order).(Syed Mujawar Hussain Shah, n.d., pp.38-53)

Syed Mujawar Hussain Shah, however, did not ignore the due role of JUP as a rightist party in the party politics in Pakistan, especially in left-right milieu. JUP emerged as a religio-political party during the first general elections held in 1970. About the outlook and electoral support of the JUP, Shah writes that "JUP enjoyed the support of the Barelvi Section of the lower strata of the population in Punjab which was under the influence of GaddiNasheens and Pirs."(Syed Mujawar Hussain Shah, n.d.) While the viewpoint of JUP leaders and ulema about socialism was construed in these words, "Socialism is a fundamental idea that had lost its efficacy . . . and Islam is a potent force that has been giving a fight to one or the other 'ism' for over 1400 years."(Syed Mujawar Hussain Shah, n.d., pp.61-68) He also mentioned about fragmentation in the JUP ranks. A dissented group under the influence of SahibzadaFaiz-ul-Hassan was supporting the leftist PPP.(Syed Mujawar Hussain Shah, n.d., p.69)

The chapter "Politics of Religion and the 1977 Elections" manifests the pinnacle of right-left dialectics. JUP's role, as part of the Pakistan National Alliance (PNA) (Syed Mujawar Hussain Shah, n.d., pp.70-71) has duly been highlighted by Syed Mujawar Hussain Shah. About the structure and functioning of the PNA, Shah reports that "Soon after the dates for elections to National and provincial assemblies were announced most of the opposition political parties with their different religious and ideological orientations came together due to their common antipathy for Bhutto and some of his domestic policies, to form a common opposition front. Nine opposition parties joined together under the umbrella of Islam to form the Pakistan National Alliance (PNA) whose leadership was controlled by three religious parties [JI, JUI and JUP]. This alliance comprised the major political parties of the country and covered the entire spectrum from the religious right to the secular left. The alliance had no alternative political agenda and was, therefore, mainly targeting at removing Bhutto from office . . . among the nine constituents of PNA, the Jamaat-i-Islami, the Jamiat Ulema-i-Islam and Jamiat Ulema-i-Pakistan were religious parties which stood for the enforcement of the Shariah. The Pakistan Muslim League and Pakistan Democratic Party were Islamist modernists. The National Democratic Party's rank and file was secular and inclined to socialism. The Khaksar Tehrik (KT) and Azad Kashmir Muslim Conference fell somewhere between the religious parties and Islamist-modernist elements; while Tehrik-i-Istiqlal was a secular party for all political purposes."(Syed Mujawar Hussain Shah, n.d.) The episode covers all the necessary details about the religion and politics of this period including the election manifestoes of the PPP and the PNA, the Islamic character of the 1977 election campaign, the election results and anti Bhutto Islamic movement (Tahrik-i-Nizam-i-Mustafa), Bhutto-PNA negotiations and fall of Bhutto regime at the hands of military chief General Zia-ul-Haq. (M. A. Khan, 2012, p.32)

Zia assumed power with the promise of holding free and fair elections and restoration of law and order situation in the country. Being a keen observer of the scene, Zia had realized that Bhutto regime had failed to fulfill the promise of Roti, 
Kapra and Makan (Salman Ghani, 2002); as a result of which the PNA had been able to attract as well as convince the masses towards its platform. That's why Zia came on the forefront with a strategy quite diverse from his predecessor Chief Martial Law Administrators (CMLAs). He was astute enough to gauge the intensity of the PNA movement and the political approach of its leadership. He adopted a two-fold policy to divert the attention of the masses from the real socio-economic and political issues and holding of elections. He tried to assure anti-Bhutto and anti-PPP elements that he was the only alternative to fulfill the demand of application of Shariah - the coveted aspiration of both the ulema and religious parties since the creation of Pakistan. Secondly, he worked on the plan to purge the influence of Bhutto and the PPP from the masses. Zia's control over PNA was unacceptable to some of the parties like JUP within PNA. Hence soon JUP parted its way from the PNA. Shah maintains that "the constituents of the PNA wanted to keep their unity in order to strengthen their political position and defeat the PPP in the coming elections. But soon PNA's internal cohesion suffered a setback because of the distribution of tickets for the October 1977 elections and JUP became disgruntled and toed the line of the Tehrik-i-Istiqlal (TI) . . . the PNA's internal strife was further intensified when Mufti Mahmud and Professor Abdul Ghafoor [Ghafoor Ahmad] were confirmed as President and Secretary-General of the PNA respectively in December 1977. All factions except JUP, NDP and TI joined the Federal Cabinet on 5 July 1978, which resulted in the demise of this alliance. There were personality, policy and factional conflicts within the PNA as well as periodic grumbling over the greater tilt of the military towards the Jamaat-i-Islami and vice versa."(Salman Ghani, 2002) The chapter "The Politics of Islam under Zia" categorically analyzes the strategy and command of Zia to curb the political scene of the country through his self- devised process of Islamization. Zia left no stone unturned to overhaul the whole socio-economic order of the society. Shah comments that "in June 1981, Zia directed the Council of Islamic Ideology (C.I.I.) to prepare a draft for an Islamic system of government . . keeping in view the conditions of the country and the interests of the Millat so that he could present to the nation . . . the framework of the political set up of the country."(Salman Ghani, 2002) However it was not until 1985, Zia revived limited political activities and held 'party-less elections'. This phase of controlled democracy was not only limited but also short-lived. Zia could not tolerate the political freedom and designs of the premier Junejo and dismissed him on 29 May 1988.("Daily Dawn," 1988)Zia was planning to reinforce his rule over the country and had once again promised to hold general elections in November 1988 but an air crash near Bahawalpur claimed his life. In this way, not only a coercive dictatorial regime ended but it led to the revival of third phase of parliamentary democracy in the country. Syed Mujawar Hussain Shah's "Religion and Politics in Pakistan (1972-1988) is a valuable piece of work on the subject and entails all the necessary details regarding the left-right politics in the country.

As far as the role of JUP in the religion and politics of Pakistan is concerned, no substantial work on the subject has been found in the political literature even in Urdu language. However, two research works direct towards the dissertation. These are Mujeeb Ahmad's Jam'iyyat Ulema-i-Pakistan 1948-1979 (Mujeeb Ahmad, 1993) and Mazher Hussain's Pakistan kay Siyasi Itehadonmein Maulana Shah Ahmad Noorani ka Kirdar [Role of Maulana Shah Ahmad Noorani in Political Alliances of Pakistan] 1970-2003.(Hussain, 2002, pp.36-37)

Mujeeb Ahmad's work Jam'iyyat Ulema-i-Pakistan 1948-1979 is a historical account of the party-its organization and functioning from its inception to the 1979. Mujeeb writes in the preface that "the Jam'iyyatulema-i-Pakistan was the first religious party to be formed after the establishment of Pakistan. Till June 1970, it functioned as a religious party and supported the ruling elites on various political issues.(Mujeeb Ahmad, 1993, p.51) However, after the 1970 Elections, it emerged as an important political party having support, mainly in rural Punjab and urban Sindh.(Mujeeb Ahmad, 1993, p.57) During the Bhutto era, it actively participated in the legislative process in the Parliament and the Provincial Assembly of Sindh. As an opposition party, it supported the cause of opposition. In 1977, it was the component party of the Pakistan National Alliance and it was mainly due to its efforts that the movement against the Bhutto government was transformed into Tahrik-i-Nizam-i-Mustafa.(Mujeeb Ahmad, 1993, p.62) After 1977, the Jam 'iyyat Ulema-i-Pakistan found it difficult to cooperate with the Martial Law authorities in any form. In July 1978, it left Pakistan National Alliance and began to function as an independent political party. The Jam'iyyat was so committed with the cause of the Nizam-i-Mustafa that, when the political parties were banned in October 1979, it continued to function under the new name of 'Tahrik-i-Nizam-i-Mustafa'."(Mujeeb Ahmad, 1993, p.63)

The work mentioned above has been divided into five chapters: Formation and Working (1948-69), the 1970 Elections and the East Pakistan Crisis, JUP: During the Bhutto Era, the 1977 Elections, Tahrik-i- Nizam-i-Mustafa and the Martial Law, and Party Constitution and Organization. Chapter one covers the period between Kashmir war 1948 and fall of the Ayub regime 1969. During the period JUP although was a party of purely religious composure yet its political adroitness could not be underestimated. Soon after the partition in 1947, it was being felt that Sunni ulema had been ignored by the ruling party Pakistan Muslim League and the ulema of ex-Congressite affiliation were getting positions in government portfolios, usurping the rights of the Ahl-i-Sunnat.(Mujeeb Ahmad, 1993, pp.63-64) Hence, Sunni ulema, like the one Maulana Ahmad SaeedKazimi, stressed the need of unity among the Sunnis in order to work under the 
leadership of an Amir Ahl-i-Sunnat for the establishment of an Islamic State in Pakistan. On his plead, the ulema and masha'ikh from different parts of the country attended a meeting at Multan on 26-28 March 1948 and in its concluding session on 28, the Markazi Jam'iyyatal-Ulema-i-Pakistan (MJUP) - the sui generis party organized after the creation of Pakistan — was formally established.(Mujeeb Ahmad, 1993, p.64) The Sunnis pledged for making Pakistan a true Islamic State and working for the elimination of all social and moral evils. They vowed for offering every kind of sacrifice for solidarity and stability of Pakistan. They also undertook to propagate Islamic teachings among the Muslims and persuade them to become committed Muslims, by initiating the spirit of religio-political awakening and the spirit of Jihad among them, and divert their attention from Western culture towards the Islamic one. They deemed to work for pan-Islamism, struggle for the prosperity of Muslim Ummah and Pakistan, and to secure peace in the world. It was also decided in the same meeting that the branches of Jam'iyyatal-Ulema-i-Pakistan would be organized all over the country and in the process peace and harmony with other religious and political organization would be given due consideration.(Mujeeb Ahmad, 1993, p.65)

Mujeeb, in the preliminary chapter, also discusses the early steps or measures taken by the JUP ranks for stressing the ruling elites for the enforcement of Shariah in the country. He mentions the efforts of JUP in helping and rehabilitating the Kashmiri refugees during the Indo-Pak war on Kashmir issue in 1948. He has given a vibrant account of JUP's participation in the constitution making process between 1949 and 1956, culminating into the enforcement of the first constitution of the country in 1956.(Mujeeb Ahmad, 1993, p.68)

In the 1950s, the religio-political issue which overwhelmed the political scene of the country was the Qadiani Issue resulting into a fierce Anti-Qadiani Movement in 1953. JUP had a clear stance on this issue and tried its level best to cope it within and without the power corridors, and interestingly it was JUP leadership in 1970s which introduced an agreed definition of the term Muslim and it was made part of the Constitution subsequently. About the collapse of the movement Mujeeb Ahmad comments that "the Tahrik-i-Khatm-i-Nabuwwat was, in fact, initiated by the Majlis-i-Ahrar-i-Islam (1929) and by the middle of 1952, various other religious parties had joined. The President of the MJUP was elected as the President of the Markazi Majlis-i-Amal mainly due to his highly prestigious personality. Maulana Qadiri [MaulanaAbul Hasanat Qadiri, the President of the aforesaid Markazi Majlis-i-Amal] was personally against the 'direct action' and ... the main reason for the collapse of the movement was the violence it generated."(Note 9)The movement was followed by a series of annual conventions of the MJUP with the name "All Pakistan Sunni Conferences' between 1955 and 1958 in order to organize the party and present its official policies about different problems and issues, on account of the interruption in holding the conventions and slowing down of the tablighi or preach work as a result of the Anti-Qadiani Movement. In the rest of the chapter, the formulation of the 1962 Constitution, the 1965 Elections and the rifts in the West Pakistan JUP, and Pakistan Democratic Movement (PDM) - a movement against Ayub Khan, have been elaborately discussed.

In the second chapter 'the 1970 Elections and the East Pakistan Crisis', the saga of the first general elections and its grim results have been commented and analyzed. Right before the elections the JUP transformed itself into a religio-political party form mere a religious one. Secondly, the JUP was in dormancy and disintegration. Before the restoration of political activity in January 1970, the Sunni Ulema made a number of attempts to create unity among the dissenting JUP factions. The chapter under discussion gives elaborative details of the efforts made for achieving harmony, and after peaceful accomplishment of this objective, JUP launched an enthusiastic election campaign. According to Mujeeb, "the elections of 1970 have a unique significance in the history of Pakistan. These elections had ideological orientation especially in West Pakistan; i.e., the issue was 'Islam verses Socialism'.”(Mujeeb Ahmad, 1993, pp.60-61)ulema, on the other hand issue a religious decree (fatwa) against Socialism, condemning that none of the systems like Socialism, Communism, Nationalism and Capitalism could be applied in Pakistan. More than 3000 ulema termed these '-isms' as kufr (infidelity) through a joint statement.(Mujeeb Ahmad, 1993, p.62) Moreover, on 2 June 1970, 118 prominent ulema from both wings of the country proposed a 23-point program on an Islamic economic system in order to counter the systems mentioned above. The signatories on this program included Maulana Shah Ahmad Noorani (1926-2003) (Note 10) and Mufti Muhammad Hussain Na'imi as the representatives of JUP and Ahl-i-Sunnat. Mujeeb also tells about the failure of JUP's leadership in joining any electoral alliance. However, JUP extended a hand of cooperation towards other like-minded rightist parties while filing its candidates. The chapter under review also gives fulsome details on the JUP candidature and manifesto, election results and grim account of disintegration of Pakistan and creation of Bangladesh out of it.(Mujeeb Ahmad, 1993, pp.62-63)

The Third chapter 'JUP: During the Bhutto Era' is the description of JUP's political and electoral activism during 1972 and 1977. It not only throws light on the autocratic behavior of Bhutto regime but also gives details of the delineated constitution making process, issue of the recognition of Bangladesh and the concluding phase of the Anti-Qadiani Movement, formation and functioning of the United Democratic Front (UDF), JUP's internal conflicts during 1972 and 1976, while the chapter four separately deals the holding of 1977 Elections and its aftermath, and finally the imposition 
of the third Martial Law and sacking of Bhutto government at the hands of General Zia. It was JUP which showed seriousness in forging an effective electoral alliance-Pakistan National Alliance-a best available combination of dissenting opposition parties. The PNA launched a fierce movement against the large scale election rigging by the Bhutto government. Although there were about twelve rounds of Bhutto-PNA negotiation but failure of any agreement on re-election gave way to PNA's movement-Tahrik-i-Nizam-i-Mustafa which in turn provided an opportunity to the establishment for overwhelming the democratic process-imposition of Martial Law. The issues of JUP's party constitution and organization have been dealt in the fifth chapter.(Mujeeb Ahmad, 1993, p.64)

Concluding his argument on JUP, Mujeeb Ahmad writes that "the JUP is a quasi-centralized party, with restricted membership. It is an association of people sharing similar creed and sect and acting together with the aim of attaining power and implementing its manifesto. The class nature of the JUP does not correspond to its title, and its social composition is based also on the businessmen, lawyers and intellectuals representing the middle class strata of Pakistani society. The Sunni Ulema, pirs and Masha'ikh are also there, to have an 'upper-hand' in the JUP. Its interpretation of the Islamic norms and injunctions is popular and liberal. Therefore, it has an appeal for the common Muslim. However, the JUP lacked an organized and well-disciplined party setup. It also lacked the scientific 'home-work' about the different policy matters and the socio-economic problems of the people of Pakistan".(Mujeeb Ahmad, 1993, p.66) The work is supported by a number of valuable supported documents appended to it. These documents include 'eleven-points drafted by Maulana Muradabadi for the Islamic Constitution', 'Office Bearers of the MJUP/JUP', 'district-wise votes polled in favour of the JUP electoral candidates for the National, Punjab and Sindh assemblies in 1970 Election', 'Names of JUP MNAs and MPAs', etc.(Mujeeb Ahmad, 1993, p.71)

Another work, in succession with the ongoing theme, is Mazher Hussain's M. Phil Thesis on the political and electoral alliances made by an eminent JUP leader Maulana Shah Ahmad Noorani i. e, "Pakistan $k$ Siyasi Itehadon mein Maulana Shah Ahmad Noorani ka Kirdar [Maulana Shah Ahmad Noorani's Role in Political Alliances of Pakistan] 1970-2003”.(Mazher Hussain, 2009) The thesis contains both rightist- and leftist-political as well as electoral alliances to which Maulana Shah Ahmad Noorani interacted favourably or otherwise. The alliances which Maulana Noorani forged included Pakistan National Alliance (PNA), Pakistan Awami Itehad, Islami Jamhuri Mahaz, and Mutahida Majlis-i-Amal (MMA). The United Democratic Front (UDF) 1972 was the only rightist alliance which was not constituted by Maulana Noorani but he supported the UDF's rightist cause. On the other hand, Maulana Noorani equally countered both the rightist and leftist alliances made in order to curb the rightist parties both inside and outside the rightist alliances. These alliances comprised Islami Jamhuri Itehad (IJI) - rightist alliance constituted with the financial assistance of the establishment, Movement for the Restoration of Democracy (MRD) — forged in 1981 by the leftist PPP and like-minded political parties in order to pressurize the Zia regime for the restoration of political activities and holding of general elections in the country. The uniqueness of the alliances initiated by Maulana Noorani, as the writer comments is that they were free of any external pressure albeit the fact that some of the component parties or their associated leaders had an announced or secret contacts with the establishment and vice versa.(Mazher Hussain, 2009) However, Maulana Noorani always discouraged and never tolerated such kind of associations or contacts within the JUP ranks. For example, during Zia regime when he felt that the PNA extended its support to the Martial Law administration, he left the PNA and the JUP leaders who later developed amiable relations with Zia and joined his nomination-based federal cabinet, he took a hard line against them and they were at least expelled from the party. Interestingly, the alliance which JUP left later died its own death.(Mazher Hussain, 2009)Maulana Noorani never interacted or supported the notions of any alliance divergent to the JUP's rightist views. Suhail Warraich, an eminent journalist of the country, is of the view that Maulana Noorani never contacted or developed cordial relations with establishment or agency for personal or party benefits. The only discrepancy on his part is that he did not leave a consolidated party or institution behind him to continue his cause. However, the role model he set in the form of his personality and practice before his followers and other politicians is worth-following to advance the national interest. Although the first experimentation of Maulana Shah Ahmad Noorani for formation and functioning with the name PNA failed to get the desired results he never lost hope and tried out a number of alliances to fulfill rightist objectives and saw consecutive failures but his last alliance, MMA, was unprecedented on the basis of results in the country's history. It was the first time that the rightist parties gained an effective position in power politics and had an important mandate on policy making. After his death in 2003, the same MMA was fell prey to 'the politics of compromise' with the corridors of power on account of the personal gains of the component parties of MMA. The work comprises seven chapters covering fulsome details regarding the alliances made during the political period under study. It reports both leftist and rightist views of different parties at alliances.(Mazher Hussain, 2009)

Another work relating to the coalition politics is Akhtar Hussain's doctoral thesis entitled "Politics of Alliances in Pakistan 1954-1999"(Akhtar Hussain, 2008)covers all those details left by research scholars on the theme. The study contains five chapters as consecutive segments in a compact study of fifteen alliances of versatile nature. As per writer's 
views, simple majority single ballot system prevails along with multi-party system to contest elections giving way to the possibility of strong alliances to be formed or encouraged with diverse nature in changing political conditions. He further says that there is no uniform and accurate way to classify political alliances because of the varying nature of alliances and dynamism of political process in which the position of various parties change with the changes in political conditions. He categorizes the alliances into opposition alliances, electoral alliances and parliamentary alliances - both government- and opposition-coalitions. In his views the opposition alliances are usually formed to cope with the authoritarian pressure of governments. The electoral are often tactful one to convert political arithmetic in the favour of allies. This sort of alliance is usually formed before elections and is directed towards evoking a favourable public response. In parliament both governmental and opposition alliances are possible to be formed. Akhtar gives all the possible details on efficacy and failure of all the three categories of alliances he describes in his work. Uniqueness of the work is its independence of the argument and judgment in an objective way. Concluding the debate on his thesis he is of the view that in the absence of well-organized and strong political parties, having a national outlook, these alliances played a pivotal role both in electioneering and opposition during the civilian and military regimes. Relation of this work to that of ours is that JUP itself remained part of a number of alliances in all the three categories cited in it.(Akhtar Hussain, 2008)

The latest of the works on coalition politics done in Pakistan is Ghulam Mustafa's doctoral thesis with the title "Politics in Pakistan: A Study of Alliances 1962-1985"(Ghulam Mustafa, 2011). The theoretical framework he puts forward covers types and life-cycle of alliances. Unlike Akhtar Hussain, he categorizes the alliances of his scope of study into three different categories i.e. pre-electoral, post-electoral and democratization alliances while another aspect missed in the preceding study is the lifecycle of the alliances spanning from formation to termination. He discusses all the categories of alliances with their life span. His study contains four broad ranging chapters on eight political and electoral alliances including Combined Opposition Parties, Pakistan National Alliance, United Coalition Party, United Democratic Front, National Democratic Front, Pakistan Democratic Movement, Democratic Action Committee, and the Movement for the Restoration of Democracy. Both theses mentioned above on coalition politics are identical and provide almost identical details on the formation and functioning of the alliances. The latter borrowed a lot of details from the former. Especially one can find much similarity between the literature reviews of the two. However, both the works indicate a shared reality that the coalition politics is one of the ignored areas of research and requires a compact study in this field of research.(Jalal, 1995, p.222)

Apart from the indigenous scholars and writers dealing with coalition politics discussed JUP's rightist role in the interplay of religion and politics in Pakistan, foreign writers also gave due mention to JUP's rightism. Aysha Jalal, Lawrence Ziring, and Ian Talbot are some of them. For example, Aysha Jalal in "Democracy and authoritarianism in South Asia: A Comparative and Historical Perspective" writes that "hard core of the anti-Bhutto movement centered around two religious parties, the Jamat-i-Islami and the Jamiat-i-Ulema-i-Pakistan." ${ }^{73}$ While discussing the interplay of right-left milieu in 1990s she observes that ". . . when the 1990 elections were held both the pro-establishment and the PPP-led People's Democratic Alliance paid far more attention to individuals with bases of support in the localities on the one hand, and the arithmetic of tribal and biraderi equations on the other than the issues of class or even religion."(Jalal, 1995, p.223) In this way she falsifies the so called leftist notions of the PPP on one hand and the use of religion as a tool to attain personal pursuits at the hands of religious parties. Interestingly, JUP was not part of the Islamic Democratic Alliance - a rightist alliance to cope or curtail leftist PPP-made in 1988 and reconstituted in 1990.(Jalal, 1995) Same is the case with Lawrence Ziring who mentions JUP's effective role in detail not only in PNA to oust Bhutto but also commends its efforts for the restoration of democracy in the face of authoritarian Zia regime.(Ziring, 1997, p.461)In "Pakistan in the Twentieth Century: A Political History"(Ziring, 1997, p.464), while commenting on the failure of MRD he writes, "it was at this point that the more conservative and fundamentalist Islamic parties formally broke with the Zia regime. Along with the Jamaat-i-Islami, the Jamiatul-Ulema-i-Pakistan, too, joined in a collective display of disaffection. The president of JUP, Shah Ahmad Noorani, citing the failure of MRD, called for still another, but more effective, coalition, whose central and sole purpose would be to defeat and ultimately oust ZiaulHaq."(Ziring, 1997) However, JUP never remained part of MRD, considering that MRD's aim was to empower leftist-cum-authoritarian PPP which was, in one way, responsible for bringing Zia into power through aftermath of 1977 General Elections.(Ziring, 1997) Ziring, confusingly showed JUP part of MRD while it mere had sympathy with the movement with the single sole condition that it led to the rehabilitation of the democratic process in the country. (Ziring, 1997, p.477) Ziring, however, is true about the rifts which martial law regime opened in opposition ranks including JUP.(Ziring, 1997) While Ian Talbot, with reference to S. Akhtar, commends that JUP, which supported Pakistan Movement unconditionally, kept distance from Zia regime contrary to other religious parties.(S. Akhtar, 1989)

The careful and curious analysis of the different narratives mentioned above clearly manifests that the religio-political right, especially the JUP emerged as a powerful stakeholder on national and international issues. However, it promoted 
its self-image as a 'Constitutional Right' not ready to compromise on principles and national interests of the country. After 2002, it declined and its political role started diminishing.

\section{Conclusion}

In today's politics whether domestic or international, characterized by uncertainty, risk and dynamism, political parties play a vital role in shaping and reshaping domestic and foreign policies. Considerable evidence suggests that political process is inevitably incomplete without the political role of the parties. Therefore, these political parties and their multifold roles in both economy and politics of a country naturally haunt scholars to study the various aspects of these political parties. Especially those parties which come to the forefront with limited sources but unprecedented activism which once creates a great fervour in the politics not only wins the sympathies of scholars but also become input to develop new concepts and theories in relation to the poetical process. The political scenario over here in Pakistan has become both awkward and uncertain due to undue growth of political parties with different slogans and designs. As Pakistan came into existence in the name of religion, here religious parties also showed their presence one way or the other. After 9/11, when the country confronted with anti-US sentiments the religious parties not only manipulated the circumstances but they also attracted both mass as well as electoral support. The Mutahidda Majlis-i-Amal (MMA), a coalition of religious-cum-political parties, showed marvelous results and religious elements, for the first time in country's history, emerged as power brokers. JUP was not only the initiator of this alliance but also kept it alive during the political discourse. JUP's electoral record is although not encouraging yet its active presence in country's politics cannot be ignored in any way. Right from troublesome seventies to 9/11 the religious parties are the focus of attention to both national and international scholars. This role has been found in fragmentation in a number of narratives and has been analyzed to sharpen blurs to show a clear cut picture of an ignored religio-political as well as constitutional rightist party which played its game in a daring and dignified manner.

\section{References}

Akhtar, H. (2008). Politics of Alliances in Pakistan 1954-1999. Quaid-i-Azam University Islamabad: National Institute of Pakistan Studies.

Binder, L. (1961). Religion and Politics in Pakistan. Berkeley: University of California Press.

Cesar, P. P. (1970). History of Political Parties in Pakistan (1947-1958). The University of Karachi.

Cohen, S. P. (2004). The Idea of Pakistan. Brookings Institution Press.

Daily, D. (1988, May 30). Karachi.

Daily, J. (1967, December 1). Lahore.

Ghulam, M. (2011). Politics in Pakistan: A Study of Alliances 1962-1985. The Islamia University of Bahawalpur: Department of History and Pakistan Studies.

Hussain, M. (2002). Aligarh Tehreek: Samaji or Siasi Mutalia (Second). New Delhi: Anjuman Taraqqi Urdu (Hind).

Jalal, A. (1995). Democracy and Authoritarianism in South Asia: A Comparative and Historical Perspective. Cambridge University Press.

Khan, H. (2001). Constitutional and Political History of Pakistan. Oxford University Press.

Khan, M. A. (2012). We've Learnt Nothing from History: Pakistan: Politics and Military Power. Karachi: Oxford University Press.

Mazher, H. (2009). Pakistan kay Siyasi Ittehadon mein Maulana Shah Ahmad Noorani ka Kirdar-Qaumi Ittehad se Mutahidda Majlis-i-Amal tak. Joharabad: Allama Shah Ahmad Noorani Research Centre Pakistan.

Mujeeb, A. (1993). Jam 'iyyat ulema-i-Pakistan 1948-1979. Islamabad: NIHCR.

Akhtar,S. (1989). Ulema in Politics. University of York, USA.

Salman, G. (2002, October 2). Clothing, Shelter and Food. Daily Nation, p. 1. Lahore.

Sayeed, K. B. (1967). The Political System of Pakistan. Karachi: Oxford University Press.

Syed, M. H. S.(n.d.). Religion and Politics in Pakistan (1947-1988). Islamabad: NIHCR.

Symonds, R. (1987). The Making of Pakistan: By Richard Symond. Lahore: Islamic Book Service.

Ziring, L. (1997). Pakistan in the Twentieth Century: A Political History. Oxford University Press. 


\section{Notes}

1. Afghanistan Issue has been the "burning" one since the Russian invasion in 1979.

2. Taliban, ultraconservative political and religious faction, which emerged in Afghanistan in the mid-1990s following the withdrawal of Soviet troops, the collapse of Afghanistan's communist regime, and the subsequent breakdown in civil order. The faction took its name from its membership, which consisted largely of students trained in madaris (Islamic religious schools) that were established for Afghan refugees in the 1980s in northern Pakistan. The Taliban emerged as a force for social order in 1994 in the southern Afghan province of Kandahar and quickly subdued the local warlords who controlled the south of the country. [Encyclopædia Britannica (2010), Encyclopaedia Britannica Ultimate Reference Suite. Chicago:Encyclopædia Britannica.]

3. Al-Qaeda, broad-based Islamic militant organization, founded by Osama bin Laden in the late 1980s, began as a logistical network to support Muslims fighting against the Soviet Union during the Afghan War; members were recruited throughout the Islamic world. When the Soviets withdrew from Afghanistan in 1989, the organization dispersed but continued to oppose what its leaders considered corrupt Islamic regimes and foreign (i.e., U.S.) presence in Islamic lands. (Ibid.)

4. Leon Trotsky, Communist theorist and agitator, a leader in Russia's October Revolution in 1917 and later commissar of foreign affairs and of war in the Soviet Union (1917-24). In the struggle for power following Vladimir Ilich Lenin's death, however, Joseph Stalin emerged as victor, while Trotsky was removed from all positions of power and later exiled (1929). He remained the leader of an anti-Stalinist opposition abroad until his assassination by a Stalinist agent.(Ibid.)

5. The politics of Alliances in the country initiated right from the formation of the United Front in East Pakistan during 1954 Provincial Elections.

6. General Muhammad Zia-ul-Haq, Pakistani Chief of Army Staff, Chief Martial Law Administrator, and president of Pakistan (1978-88); Bhutto promoted him to lieutenant general in 1975 and made him chief of Army staff in 1976.Zia seized power from Bhutto in a bloodless coup on July 5, 1977, and became chief martial-law administrator while retaining his position as Army chief of staff. He assumed the presidency after Fazal Elahi Chaudhry resigned in 1978.

7. Iranian society in reaction to the steps taken to modernization stood and sided with Khomeini, a religious-cum-spiritual leader. In January 1978, incensed by what they considered to be slanderous remarks made against Khomeini in a Tehran newspaper, thousands of young madrassa students took to the streets. They were followed by thousands more Iranian youth - mostly unemployed recent immigrants from the countryside-who began protesting the regime's excesses. During his exile, Khomeini coordinated this upsurge of opposition-first from Iraq and after 1978 from France - demanding the shah's abdication. In January 1979, in what was officially described as a 'vacation', he and his family fled Iran; he died the following year in Cairo. On April 1, following overwhelming support in a national referendum, Khomeini declared Iran an Islamic republic.

8. General Muhammad Ayub Khan (1907-1974), president of Pakistan from 1958 to 1969, whose rule marked a critical period in the modern development of the country. After the 1947 partition of British India he was rapidly promoted in the army of the new Muslim state of Pakistan: from major general (1948) to commander in chief (1951). In addition, Ayub became minister of defense (1954) for a brief period. In 1958 President Iskander Mirza, with army support, abrogated the constitution and appointed Ayub as chief martial law administrator. Soon after, Ayub had himself declared president, and Mirza was exiled.

9.Khatm-i-Nabuwwat is the seal of the prophet hood; finality of the prophet hood, an epithet of the Prophet (SAW). Muslims believe in the finality of prophet hood; in 1953 a movement was launched against the Ahmadis but was put down by the Punjab Government; finally on 7 September 1974, the issue was resolved through an amendment in constitution declaring Ahmadis as non-Muslim.

\section{$(\mathrm{cc}) \mathrm{Br}$}

This work is licensed under a Creative Commons Attribution 3.0 License. 